IZA DP No. 4640

Seeking Similarity: How Immigrants and Natives Manage at the Labor Market

Olof Åslund

Lena Hensvik

Oskar Nordström Skans

December 2009 


\title{
Seeking Similarity: How Immigrants and Natives Manage at the Labor Market
}

\author{
Olof Åslund \\ IFAU, Uppsala University, \\ CReAM and IZA \\ Lena Hensvik \\ IFAU and Uppsala University \\ Oskar Nordström Skans \\ IFAU, Uppsala University \\ and IZA
}
Discussion Paper No. 4640
December 2009

\author{
IZA \\ P.O. Box 7240 \\ 53072 Bonn \\ Germany \\ Phone: +49-228-3894-0 \\ Fax: +49-228-3894-180 \\ E-mail: iza@iza.org
}

\begin{abstract}
Any opinions expressed here are those of the author(s) and not those of IZA. Research published in this series may include views on policy, but the institute itself takes no institutional policy positions.

The Institute for the Study of Labor (IZA) in Bonn is a local and virtual international research center and a place of communication between science, politics and business. IZA is an independent nonprofit organization supported by Deutsche Post Foundation. The center is associated with the University of Bonn and offers a stimulating research environment through its international network, workshops and conferences, data service, project support, research visits and doctoral program. IZA engages in (i) original and internationally competitive research in all fields of labor economics, (ii) development of policy concepts, and (iii) dissemination of research results and concepts to the interested public.
\end{abstract}

IZA Discussion Papers often represent preliminary work and are circulated to encourage discussion. Citation of such a paper should account for its provisional character. A revised version may be available directly from the author. 


\section{ABSTRACT \\ Seeking Similarity: How Immigrants and Natives Manage at the Labor Market ${ }^{*}$}

We show that immigrant managers are substantially more likely to hire immigrants than are native managers. The finding holds when comparing establishments in the same 5-digit industry and location, when comparing different establishments within the same firm, when analyzing establishments that change management over time, and when accounting for within-establishment trends in recruitment patterns. The effects are largest for small and owner-managed establishments in the for-profit sector. Separations are more frequent when workers and managers have dissimilar origin, but only before workers become protected by EPL. We also find that native managers are unbiased in their recruitments of former coworkers, suggesting that information deficiencies are important. We find no effects on entry wages. Our findings suggest that a low frequency of immigrant managers may contribute to the observed disadvantages of immigrant workers.

JEL Classification: J15, J21, J62, M51

Keywords: minority workers, labor mobility, workplace segregation

Corresponding author:

Olof Åslund

IFAU

Box 513

SE-751 20 Uppsala

Sweden

E-mail: olof.aslund@ifau.uu.se

\footnotetext{
* We are grateful for comments by Mikael Lindahl, Lena Magnusson-Turner, Eva Mörk, Peter Skogman Thoursie and seminar participants at IFAU, IBF, the 2008 Cost Conference in Paris, the ELE Immigration Conference in Helsinki, the labor lunch workshop at Harvard University, the Nordic Labor Economists meeting in Bergen, the 2009 Swedish Integration Research Network Conference in Lund, and the 2009 SOLE and EEA conferences. Financial support from FAS is gratefully acknowledged. The order of the authors is in accordance with the English alphabet and not related to contribution.
} 


\section{Introduction}

Managers are key players in the labor market. At the micro-level, managers make hiring decisions and determine wages, processes that are central to individual workers. In the aggregate, managerial behavior affects the wage distribution within and across establishments, and the allocation of skill across industries. Despite the central decisionmaking role of managers, little attention has been given to the importance of managers for individual labor market outcomes. In this paper we study a particular form of manager influence: Do immigrant managers hire more immigrant workers?

Non-western immigrants perform poorly at the labor market in most OECD countries. Sweden, from where we take our data, is no exception. An aspect of this which is largely overlooked in the previous literature is that the same groups of immigrants are also severely underrepresented in managerial positions. ${ }^{5}$ While supply side factors, such as human capital and economic incentives, have been studied extensively in the past as potential explanations for the poor performance of immigrants in western countries, the discussion about the demand side has almost exclusively focused on the role of discrimination. ${ }^{6}$ Recent studies document strong patterns of ethnic segregation across workplaces in the US (Hellerstein and Neumark, 2008), Sweden (Åslund and Skans, 2009) and Germany (Dustmann et al., 2009), suggesting that there are important differences in hiring patterns between observationally equivalent firms. The analysis in this paper shows that manager characteristics are an important explanation to why certain firms hire minority workers from disadvantaged groups, while others do not.

Due to the non-random sorting of managers across firms it is generally difficult to distinguish the causal impact of manager characteristics from spurious relationships generated by unobservable characteristics. Studies relying on cross-sectional data have

\footnotetext{
${ }^{5}$ We show that although 7.2 percent of the recently hired employees in our data are of immigrant origin, only 3.7 percent of the managers belong to this group.

${ }^{6}$ Field experiments point at substantial ethnic discrimination in the hiring procedure against African-Americans in the US (Bertrand and Mullainathan, 2004) and workers of Middle-Eastern descent in Sweden (Carlsson and Rooth, 2007). In addition, laboratory experiments suggest that people tend to favor/trust others with a similar ethnic background (e.g. Fershtman and Gneezy, 2001 and Ahmed, 2007). For quasi-experimental evidence of discrimination in actual recruitments, see Åslund and Skans (2007).
} 
documented correlations between manager race and the race of hires (Carrington and Troske 1998; Stoll et al. 2004). To facilitate more reliable identification, a number of recent papers have relied on single firm data from high turnover firms. Bandiera et al. (2009) study the importance of social connections between the manager and employees for the allocation of jobs within a British fruit-picking farm where workers are allocated to jobs on a day by day basis. Two papers by Giuliano et al. (forthcoming, 2009) study ethnic biases in hiring and firing in a large US retail chain.

These recent studies all provide compelling evidence of a causal effect of manager race/ethnicity on hiring patterns in the studied firms. The advantage of the data sets they use is the detailed longitudinal information on workers and managers, and in the case of Bandiera et al. (2009) also observable worker productivity. ${ }^{7}$ However, it is an open issue whether the results can be generalized to a wider set of jobs, where jobs may be rationed and turnover low.

Our study adds to this literature by analyzing longitudinal data on more than 100,000 Swedish workplaces across the entire economy during a nine-year period, and with coworker information going even further back in time. The data allow us to implement various strategies to account for unobserved heterogeneity among workers, managers and firms, and to investigate different potential mechanisms. Furthermore we study a labor market where the recruitment decisions are likely to be crucial for both workers and firms due to high unemployment among minority workers and relatively stringent employment protection legislation.

Our analysis reveals the following facts about manager origin and recruitment patterns:

(1) Immigrants are severely underrepresented among managers. Although 7.2 percent of the hires in our data are non-western migrants, only 3.7 percent of the managers come from this group.

\footnotetext{
${ }^{7}$ A closely related literature studies managers from a gender perspective and shows a positive correlation between female management and female wages (Carrington and Troske 1995; Hultin and Szulkin 2003). Using a matched employer-employee dataset for Portugal, Carduso and Winter-Ebmer (2007) estimate the effect of withinestablishment manager changes and find that female-led firms pay a premium to female workers of almost 5 percent.
} 
(2) The hiring patterns of immigrant managers and native managers are very different: Immigrant managers recruit 43 percent immigrant workers whereas the corresponding number for other managers is 6 percent.

(3) Even very similar (5-digit industry) establishments in the same localities differ systematically in their recruitment patterns depending on the origin of the manager. This pattern holds also when we compare different establishments within the same firm or follow the same establishments over time, even after accounting for establishment level trends. The estimates are robust and both economically and statistically significant throughout.

(4) The effect is present in workplaces of different sizes, in both the private and public sector, and in most industries. But the evidence also suggests that manager origin has a larger impact when the manager has a bigger stake in profits and when uncertainty should be more of a concern, i.e. in small and owner-managed companies and in the for-profit sector.

(5) Separations are more frequent when workers and managers are of dissimilar origin. This effect is entirely driven by workers who are unprotected by employment protection legislation.

(6) There is no evidence of an impact on entry wages from sharing origin with the manager. Productivity gains can therefore not be the sole underlying mechanism unless starting wages are independent of match-specific productivity.

(7) Manager-worker similarity matters also when managers hire former co-workers, but this effect is completely driven by immigrant managers. The absence of an effect among native managers could indicate that information asymmetries (which are substantially reduced in the former co-worker setting) are an important explanation for the baseline results.

The remainder of the paper is structured as follows. Section 2 briefly discusses the theoretical arguments on the importance of manager origin for hiring patterns and the institutional background. Section 3 presents the data. Section 4 provides some descriptive patterns and sample statistics. Section 5 presents the results on the impact of manager origin on the origin of hires. The methodological approaches are presented in 
conjunction with the empirical results. Section 6 analyzes the role of origin when managers hire former co-workers. Section 7 concludes.

\section{Background}

\subsection{Why could manager origin matter?}

A hiring constitutes a match between the individual and the workplace. The behavior of both parts, as well as the total surplus from a realized match, may therefore matter for who gets hired. Below we briefly discuss different explanations for why ethnic similarity between workers and managers may be important for recruitment patterns. In the presentation of the empirical results and in the conclusions we try to link the findings to the respective hypotheses.

First, workers who have a similar background as their manager may become more productive. A common language or business culture can e.g. lower transaction and communication costs (Lazear 1999; den Butter et al., 2004). A case where this mechanism should be particularly relevant is enterprises providing specific "ethnic" goods and services (e.g. restaurants). ${ }^{8}$

Second, systematic sorting can arise due to preferences among the agents. In Becker's (1957) discrimination model, some-but not all-employers are unwilling to hire minority workers at the majority wage simply because they derive disutility from doing so. Group-biased preferences among majority and/or minority managers would lead to a relationship between manager origin and workforce composition. It should be noted that preferences can be important on both sides of the recruitment decision, i.e. not only among managers but also among (potential) applicants. In fact, Giuliano et al. (forthcoming) argue that worker preferences are the key factor for why black managers recruit less white applicants in the retail firm they study.

A third explanation is informational asymmetries. Theories of statistical discrimination often assume that managers find it more difficult to value merits and qualities among applicants with a different background than themselves. Managers may 
therefore prefer to hire workers who are similar to themselves if acquiring information is costly. Conversely, it is conceivable that workers have difficulties valuing managers with a background that differs from their own.

Fourth, networks could be important if they provide information on the availability and quality of workers and/or vacancies (see e.g. Montgomery, 1991; Calvo-Armengol and Jackson, 2004 and Granovetter 1973). There is a large and growing empirical literature suggesting that social networks are very important when workers get hired; Ioannides and Loury (2004) provide a survey. Individuals who live in the same residential area are more likely to work together (Bayer et al., 2008), parents help their children to find their first job (Kramarz and Skans, 2007), former co-workers share information about new jobs (Cingano and Rosalia, 2008), and immigrants with larger exogenous networks are more successful in the labor market (Munshi, 2003). A series of recent papers provide indirect evidence that ethnic labor market networks are important for black and Hispanic workers in the US (Hellerstein and Neumark 2008; Hellerstein et al. 2008a, 2008b and 2009) and for immigrants in Germany (Dustmann et al, 2009)

It is noteworthy that most of this previous literature focuses on the effects of social contacts among employees, and not on the manager specifically. Managers are expected to use social contacts if they have higher utility of employing workers whom they know, or if informal hiring methods imply lower recruitment costs. In the hiring process, networks formed at professional arenas can be of particular importance. Managers may hire individuals of their own origin simply because they have met more people sharing their own background, e.g. at previous workplaces. Moreover, there is a distinction in the literature between baseline homophily which means that networks of similar individuals arise because of the demographics of the available network pool, and inbreeding bias, which is the excess effect of similarity arising because individuals associate more with similar people given their available network (see e.g. Currarini et al., 2008 and McPherson et al., 2001 for studies on homophily). We return to this

\footnotetext{
${ }^{8}$ In terms of our empirical model, preferences that affect productivity (such as customer preferences or preferences among the existing stock of employees) could also be included in this category.
} 
distinction when discussing informal hiring patterns in recruitments of former coworkers in Section 6.

\subsection{Immigrants at the Swedish labor market}

Since 1960, the number of first-generation immigrants living in Sweden has grown from 300,000 to more than one million. Today, the foreign-born constitute about 13 percent of Sweden's nine million residents and define most of the country's diversity in terms of origin or ethnicity.

As in many other western countries the labor market position of the immigrant population has deteriorated during the last thirty years. In the 1950s and 1960s, labor migration from the Nordic countries (especially Finland) and continental Europe dominated the inflow. Immigration then gradually shifted toward refugees and family reunification migrants, many times from developing and geographically distant countries (e.g. Chile in the 1970s, Iran from the 1980s, Somalia and former Yugoslavia in the early 1990s, and Iraq in the 1990s and 2000s.)

Even though natives on average perform better in the labor market than almost all groups of migrants, the great divider seems to be between those of western and nonwestern origin. In 2002 (in the midst of our observation period, see below), the employment rate among natives was 76.8 percent. The corresponding figure for EU/EES migrants was 69.3 percent, compared to 53.5 percent among those born outside Europe. Wage differences are smaller, but follow the same pattern: the average monthly (full-time) wage among natives was SEK 22,250 in 2002; for immigrants from nonEuropean countries it was SEK 19,050, while EU migrants had an average wage almost identical to the one received by natives. ${ }^{9}$ For a further discussion of these differences and their possible causes, see e.g. Eriksson (2007).

\footnotetext{
${ }^{9}$ Figures for employment and unemployment come from the Swedish labor force surveys. Wages are calculated from the LINDA database (see Edin and Fredriksson 2000), which contains a three-percent representative sample of Sweden's population.
} 


\section{Data}

Our primary source of data is a Swedish linked employer-employee database (RAMS) covering the period 1985 to 2005. We can derive information about each establishment's manager for all workplaces in the public sector as well as for a large sample of private firms. The main sample consists of managers and employees in workplaces with less than 50 employees in the years 1997 to 2005. The rational for restricting the analysis to small and medium sized establishments is that it is more likely that the manager is directly involved in the hiring and firing decisions in such establishments. ${ }^{10}$ Further, the data allow us to track managers, employees and establishments over time and link each of these subjects to detailed information on individual demographic characteristics (gender, age, region of birth, education and place of residence) as well as to basic information about each establishment (location, industry and sector). Our main working data set includes all newly recruited workers in establishments with less than 50 employees during the period 1997 to 2005 together with information on the immigration status of each worker and manager.

\section{Managers and wages}

We use a register (Strukturlönestatistiken) containing occupation and wages for a large sample of firms to identify managers. Borrowing from Carduso and Winter-Ebmer (2007) we use the following hierarchical criteria: (1) Owner of the firm; (2) Top manager; (3) Middle manager; (4) Highest wage. In case there are multiple observations fulfilling the same criterion we use lower ranked criteria to identify the manager (e.g. the middle manager with the highest wage). ${ }^{11}$ This strategy is likely to introduce some

\footnotetext{
${ }^{10}$ Since previous research shows that segregation is most prevalent among small to medium sized establishments (see e.g. Åslund and Skans, 2009) our results are not necessarily representative for larger establishments. However, given that the data show that the median worker is employed in an establishment with 52 employees (2001), we cover a substantial part of the workforce.

${ }^{11}$ To increase sample size (particularly in the establishment fixed effect estimations), we use also information from population-wide data on estimated monthly wages (see for example Skans, Edin and Holmlund, 2009 for procedures). If an establishment is sampled at two separate points in time with the same manager, the same person is assumed to be manager also in the years in between (provided he/she is at the establishment). If the sample data identifies a manager in one year, the same person is assumed to be manager in all continuously preceding and following years in which he/she has the highest estimated wage (and where the establishment is not sampled).
} 
measurement error in the manager code and robustness checks to address this concern is discussed in the empirical section.

The raw occupational data is structured according to the Swedish Standard for Classification of Occupations (SSYK), which is based on international standards (ISCO-88). The first digit in the occupational code divides the data into ten major occupational levels based on the skill requirements and with a specific number for managerial positions. Using additional digits, we can also distinguish between top and middle managers. In addition to occupational information, we use information on ownership which is available for all establishments.

The data on occupations and wages cover all establishments in the public sector but are sampled at the firm level for the private sector. The sampling probabilities depend on firm size which implies that we will have an under-representation of establishments belonging to smaller private firms in our full sample. We therefore also present results separately for each firm size bracket (i.e. each stratum). Although the sampling probabilities are small for small firms, many large firms have small establishments, and thus our final dataset covers approximately 30 percent of all small and medium sized private establishments (Table A2, Appendix).

\section{Origin classification}

The main analysis aggregates the individuals by their country of birth into two categories: (i) workers of Western origin i.e. natives and immigrants from Western countries; (ii) immigrant workers of Non-Western origin. For convenience, we label the groups "Natives" and "Immigrants". This division is consistent with the main divider in terms of differences in labor market outcomes, and also with the public perception of “being foreign” (see e.g. Mella and Palm, 2009). We also present robustness checks using four groups (“Native”, “Western”, “Eastern Europe”, and “Non-Europe”). ${ }^{12}$ In addition, where the specification allows for it, we utilize more detailed information on the individual's country of origin and investigate the differential impact of immigrant

\footnotetext{
${ }^{12}$ Using a finer grouping yields very few managers of some origin types.
} 
managers on the hiring probabilities for own-country versus other-country workers (see Table A1 in Appendix A for a list of countries).

\section{Data on hired workers}

We create data on new hires for the years where we have information on managers, i.e. 1997-2005. A new hire is a worker who received remuneration from the establishment in a given year, but not during any of the preceding five years. We disregard individuals earning below the $10^{\text {th }}$ percentile of the overall annual earnings distribution in order to avoid classifying very loosely connected (i.e. working a few hours within the year) workers as new hires. We are primarily interested in recruitments within continuing plants and therefore require that the establishment existed in the preceding year. For the same reason we also classify an establishment as new (and remove it) if more than 2/3 of the workforce changed (in either direction) from one year to the next. ${ }^{13}$

\section{Data on recruitments of former colleagues}

The long panel of individuals and establishments allows us to create a unique dataset containing all cases where newly hired worked with their hiring manager sometime in the past. In practice we follow each hired worker and his/her manager from the year of the hire and back to the start of our data (1985) and if they are found in the same workplace anytime during this period, we take the last year this happens and add all other co-workers from that establishment and year to the data.

To minimize the risk of simultaneity and/or reverse causality we include only cases where the manager worked at the new establishment the year before the hire. We also restrict the analysis to individuals that worked together in an establishment with less than 100 employees. The reason is that we want it to be likely that the two agents interacted at the old workplace so that they were able to eliminate uncertainty about each other's productivity. We do not however put any restriction on the manager's occupational level at the past workplace. Thus he or she did not have to be a manager at the previous job. The only restriction is that the manager and the hire received 
compensation from the same establishment during the same year at some point from 1985 and up to the new hiring.

\section{Descriptive patterns: Migrant status among managers and the newly-hired}

Before proceeding with the more formal analysis we show some key descriptive statistics from our sample. Figure 1 presents the share of immigrant hires and managers, overall and by industry. Two important facts are visible in the figure: First, the top bars show that immigrants are underrepresented among managers in relation to their share of hires. Whereas 7 percent of the hired workers are immigrants the corresponding number for managers is only 3 percent. ${ }^{14}$ Second, there is systematic sorting across industries both among hired workers and managers; the representation of immigrants is much higher in "hotels and restaurants" and "transportation" than in other industries. Overall industries with few immigrant managers also hire a lower than average share of immigrant workers.

\footnotetext{
${ }^{13}$ When checking that new hires did not receive earnings from the same establishment in the past we use the original workplace identification number in order to make sure that the hires were really externally recruited.

${ }^{14}$ Official statistics from the 2007 labor force surveys confirm this picture for the overall population of employees: 6 percent of all native employees are managers whereas the figure is less than 2 percent for immigrants from nonEU/EES countries.
} 


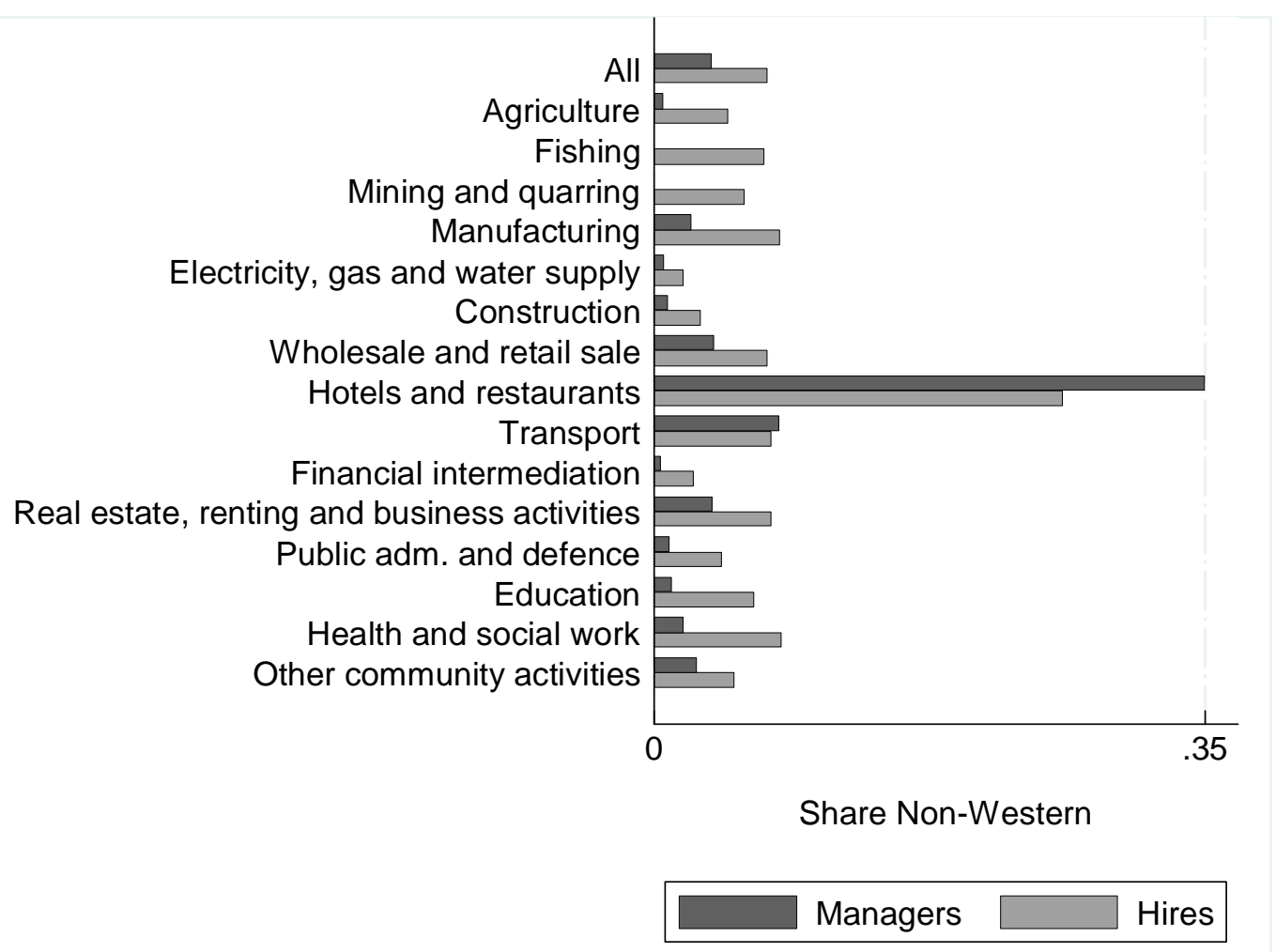

Figure 1 Share of Immigrant managers and hires in different industries

Table 1 presents further statistics. These clearly show that the sectoral sorting displayed in the above figure also carries down to the establishment level. A substantially higher share of immigrants works for immigrant managers. This holds also for the newly hired and the differences are enormous: the share of immigrants hired under immigrant management is 43 percent, compared to 6 percent in other establishments. Thus, immigrant managers hire immigrant workers with a 7 times higher probability than other managers. About half of the immigrant workers that are hired by immigrant managers are from other countries than the manager (not in table). In other words, hiring countrymen is common, but it is also the case that immigrants hire other foreignborn workers to a much larger extent than do native managers. We also see that immigrant managers manage smaller establishments, hire fewer individuals and operate in more immigrant dense municipalities than native managers. 
Table 1 Sample Statistics

\begin{tabular}{|c|c|c|c|}
\hline & $(1)$ & $(2)$ & (3) \\
\hline Manager origin: & ALL & Native & Immigrant \\
\hline \multicolumn{4}{|l|}{ Establishment characteristics: } \\
\hline Immigrant hires & 0.07 & 0.06 & 0.43 \\
\hline Immigrant share & 0.05 & 0.04 & 0.43 \\
\hline Establishment size & 24.3 & 24.5 & 17.9 \\
\hline New Hires/Establishment and year & 5.0 & 5.0 & 4.02 \\
\hline [Sd] & [3.73] & [3.74] & [3.34] \\
\hline Immigrant share in mun. and 5-digit industry & 0.06 & 0.05 & 0.20 \\
\hline \multicolumn{4}{|l|}{ Manager type: } \\
\hline Owner & 0.09 & 0.07 & 0.51 \\
\hline Top Manager & 0.14 & 0.14 & 0.08 \\
\hline Middle Manager & 0.24 & 0.24 & 0.07 \\
\hline Highest wage & 0.53 & 0.54 & 0.33 \\
\hline \multicolumn{4}{|l|}{ Manager origin } \\
\hline Native (treated as "natives") & 0.94 & 0.96 & - \\
\hline Western countries (treated as "natives") & 0.04 & 0.04 & - \\
\hline Eastern Europe (treated as "immigrants") & 0.01 & - & 0.40 \\
\hline Other (treated as "immigrants") & 0.02 & - & 0.60 \\
\hline Observations $^{(1)}$ & 843,085 & 818,752 & 24,333 \\
\hline
\end{tabular}

Notes: ${ }^{(1)}$ The level of observation is the individual. The sample consists of all establishments that hired at least one individual during the period 1997-2005. The classification of "native" and "immigrant" managers is motivated in section

Turning to the manager characteristics we see that a much larger fraction of the immigrant managers are owners (51 percent vs. 7 percent of native managers), which is in line with self-employment being comparatively prevalent in this group. A large share of both the native and the immigrant managers are identified by their wage. This is a potential concern since measurement error is likely to be prevalent in this group of managers. To deal with this we also present results for the impact of manager origin separately by manager classification in the analysis below.

\section{$5 \quad$ Empirical analysis}

\subsection{Hiring patterns}

We estimate the effect of manager origin on the origin of new hires using linear probability models of the following type: 


$$
H_{i j t}^{i m}=\gamma M_{j t}^{i m}+X_{j t} \beta+\varepsilon_{i j t}
$$

where $H$ is an indicator for whether the hired individual $i$ in establishment $j$ in year $t$ was immigrant (im); $M$ is a dummy variable for immigrant manager; $X$ is a vector of control variables and $\varepsilon$ is the error term. Our aim is to identify the causal impact of manager origin on the probability that new hires are immigrants. In order to do so we need to remove potential confounding factors. We therefore exploit a number of alternative identification strategies, all implemented as variation of controls in the $\mathrm{X}$ vector of equation (1). These are described below together with the results.

\subsubsection{Baseline results}

Table 2 presents results from estimation of equation (1). ${ }^{15}$ The dependent variable is the probability that a hired worker is of immigrant origin and the covariate of interest is a dummy for whether the manager is immigrant. All specifications include year dummies to account for national trends in recruitment patterns and workplace size dummies in 10 employee intervals. Other controls vary between columns.

The estimate of 0.369 in column 1 confirms the substantial raw correlation between manager origin and the origin of new hires shown in the previous section. In column (2) we remove the impact of regional sorting by introducing 289 municipality dummies. This only marginally reduces the estimate. We have also verified that the result holds if we replace municipality indicators by neighbourhood indicators. Thus, regional sorting is not driving the raw correlation.

In column 3 we compare similar firms in the same regions by including dummies (fixed effects) for each combination of year, municipality and industry (at the 5-digit level). Most of the estimated effect remains - the estimate is 0.244 . It is noteworthy that the 5-digit industry codes are quite detailed. The specification implies that we, for example, compare hiring patterns between different pharmacies (code 52310) or taxi businesses (60220) located in the same area (the average municipality has 30,000

\footnotetext{
${ }^{15}$ A logit specification instead of the linear probability model yields very similar results in the cases where we can test it.
} 
residents). Thus, manager origin is highly correlated with the origin of new hires even when establishments are both similar and located nearby.

In order to account for remaining unobservable confounders, column 4 includes the share of immigrants among the other employees (excluding the manager and new hires) at the establishment as a covariate. This substantially reduces the coefficient, but the estimate is still large (0.123) and highly significant. ${ }^{16}$ Hence, even when we compare two firms in the same industry, year and geographic area, and also take into account the demographic composition of the current workers, the probability that the newly hired is an immigrant is nearly three times as high if the manager is also of immigrant origin (the overall share of immigrant hires is 7 percent). ${ }^{17}$ Using finer neighborhood indicators does not alter any of the results. ${ }^{18}$

When interpreting these results it is important to note that they do not imply perfect, or even increasing, segregation over time. The reason is that the job durations are finite, and the sorting less than perfect. Thus, even if firms with an immigrant manager and a high share of immigrant workers tend to hire more immigrants, they will not necessarily end up having a homogenous workforce since some workers will leave, and some of the workers who replace those who leave will be natives.

Finally in column 5 we allow the estimates to vary depending on the type of manager. The effect is substantially larger in owner-managed establishments than in establishments with other types of management, an issue we will return to below. Importantly, however we find large and significant effects for all types of managers; 5 percentage points implies close to a doubling of the probability.

\footnotetext{
${ }^{16}$ We have also verified that the origin of the manager is significantly more important than the origin of other workers by re-estimating the model with the manager included in the share of incumbent immigrant workers.

${ }^{17}$ Interestingly, our estimated effect from the share of immigrant co-workers is not far off from what Dustmann et al. (2009) found for Germany in a similar specification.

${ }^{18}$ When replacing municipalities with neighborhood indicators ("SAMS") which on average contain a population 1000 inhabitants (all ages) the estimate for column 2 (3) [4] becomes 0.321 (0.177) [0.102], all with standard errors around 0.01 .
} 
Table 2 OLS estimates of manager origin on origin of new hires

\begin{tabular}{|c|c|c|c|c|c|}
\hline & \multicolumn{5}{|c|}{ Dependent variable: $\operatorname{Pr}($ Hire is Immigrant) } \\
\hline & (1) & (2) & (3) & $(4)$ & (5) \\
\hline Immigrant manager & $\begin{array}{l}0.369 * * * \\
(0.007)\end{array}$ & $\begin{array}{l}0.332^{\star \star \star} \\
(0.006)\end{array}$ & $\begin{array}{l}0.244^{\star \star *} \\
(0.007)\end{array}$ & $\begin{array}{l}0.123^{\star * *} \\
(0.005)\end{array}$ & \\
\hline Owner & & & & & $\begin{array}{c}0.260^{\star \star \star} \\
(0.009)\end{array}$ \\
\hline Top manager & & & & & $\begin{array}{l}0.059 * * * \\
(0.015)\end{array}$ \\
\hline Middle manager & & & & & $\begin{array}{l}0.036^{\star *} \\
(0.016)\end{array}$ \\
\hline Highest wage & & & & & $\begin{array}{l}0.052^{\star \star \star} \\
(0.007)\end{array}$ \\
\hline $\begin{array}{l}\text { Share immigrants at } \\
\text { establishment }\end{array}$ & & & & $\begin{array}{c}0.466^{\star * *} \\
(0.008)\end{array}$ & $\begin{array}{l}0.415^{\star \star \star} \\
(0.008)\end{array}$ \\
\hline Firm size dummies & Yes & Yes & Yes & Yes & Yes \\
\hline Year dummies & Yes & Yes & Yes & Yes & Yes \\
\hline Mun-Year dummies & No & Yes & Yes & Yes & Yes \\
\hline Mun-Ind-Year dummies & No & No & Yes & Yes & Yes \\
\hline Observations & 843,085 & 843,085 & 843,085 & 843,085 & 843,085 \\
\hline $\mathrm{R}^{2}$ & 0.059 & 0.087 & 0.251 & 0.272 & 0.274 \\
\hline $\begin{array}{l}\text { Notes: Each column repres } \\
\text { percent level respectively. } \\
\text { shown in parentheses. The } \\
\text { indicates whether the new } \\
\text { native. Industry codes are } \\
\text { less than } 50 \text { employees an } \\
\text { intervals. The share of imm } \\
\text { require that the establishm }\end{array}$ & $\begin{array}{l}\text { s a separa } \\
\text { idard erro } \\
\text { imated mc } \\
\text { was nativ } \\
\text { e } 5 \text {-digit e } \\
\text { regressio } \\
\text { ints is the }\end{array}$ & $\begin{array}{l}\text { ression. *, } \\
\text { ust for seri } \\
\text { a linear p } \\
\text { r immigrai } \\
\text { hment lev } \\
\text { lude contr } \\
\text { when the }\end{array}$ & $\begin{array}{l}* \star \star \\
\text { elation at } \\
\text { lity model } \\
\text { The omitte } \\
\text { e sample c } \\
\text { establishr } \\
\text { ger is exclt }\end{array}$ & $\begin{array}{l}\text { stical sign } \\
\text { tablishme } \\
\text { the depe } \\
\text { egory on } \\
\text { ts of estal } \\
\text { ize of ten } \\
\text { hence all }\end{array}$ & $\begin{array}{l}\text { e at } 10 / 5 / 1 \\
\text { l are } \\
\text { variable } \\
\text { er origin is } \\
\text { ents with } \\
\text { yee } \\
\text { cations }\end{array}$ \\
\hline
\end{tabular}

\subsubsection{Comparisons within firms and establishments}

Even though the specifications presented above are quite rich, one could still worry about remaining unobserved characteristics that are correlated with the origin of the manager. To verify the robustness of our results we perform a series of specification tests addressing concerns about endogenous workplace selection of managers, common shocks, and trends in hiring patterns.

In order to remove (potentially year specific) unobserved heterogeneity at the firm level we use data from firms with multiple establishments in the same location. To handle unobserved factors at the establishment level, we use data on establishments where management changed from native to immigrant (or vice versa) during our sample 
period. As shown in Table A3 both of these criteria basically exclude all ownermanaged establishments. ${ }^{19}$. To evaluate the importance of unobserved heterogeneity, we should therefore compare the estimates from the firm/establishment fixed effects models to a baseline specification excluding owners; this is done below. For comparison, columns (1) and (2) of Table 3 present the baseline estimates both with and without owners. As already indicated in Table 2, the average effect is smaller without owners (but still large and significant).

\section{Firm fixed effects}

We first analyze within-firm variations. We include dummies for the combination of year, firm, municipality, and industry of the establishment. The idea is to compare establishments with the same firm-specific culture, involved in a similar production process and located in the same local labor market. Given the year interaction, this specification also handles unobserved time effects at the firm level (e.g. changes in a firm's human resource policies). We only include firms in the private sector. As shown by Table A3 the establishments which fulfill these criteria are often found in consumer services, e.g. retailers and banks. The results, presented in column (3) of Table 3 show an estimate (0.044) very similar and not statistically different from the main model without owners (0.051).

\section{Establishment fixed effects}

Including establishment dummies in equation (1) means that we remove all fixed workplace characteristics. The specification is identified from the cases where manager origin changes over time within the establishment. Due to the large degree of segregation and the low frequency of immigrant managers, changes in manager origin are fairly unusual. In addition, the management data are based on random yearly (firmbased) samples, and the specification relies on someone actually being recruited in the sampled year. Since we need two such observations for each establishment, and a change of manager origin in-between, we end up with a relatively small dataset for this

\footnotetext{
${ }^{19}$ Due to the organization of multi-establishment firms we are not particularly surprised finding no owner defined workplaces in this category. Furthermore there are very few changes in origin ownership (they account for 2 percent of the cases, see column (3)) which may be partly explained by more persistence in this category and more informal ownership takeovers e.g. within families.
} 
specification. $^{20}$ However, column (4) shows that the establishment fixed effects estimate (0.045) is very much in line with the baseline estimate. ${ }^{21}$

\section{Establishment level trends}

An additional concern is workplace-specific trends in hiring patterns, which may generate a spurious relationship between the origin of the manager and the origin of newly hired workers. Establishments with an increasing share of immigrant hires may more often end up having immigrant managers, and increases in immigrant hires may lead to a change in manager origin. Both of these mechanisms would introduce an upward bias to our estimates.

As an additional robustness check we therefore estimated models including linear trends (centered on the year of the manager change for the interval $[-6,6]$ ) for establishments changing manager. This sample differs from the establishment fixed effects sample in that it does not require hires both before and after the manager change in the same establishment. In column (5) the trend is allowed to differ depending on the direction of the manager change and in column (6) we also let the slope differ beforeafter the change (by direction, thus 4 slopes). The estimates in these columns are, again, in the vicinity of the baseline specification (0.051 and 0.056).

\footnotetext{
${ }^{20}$ To reduce the risk of having false transitions exacerbating potential measurement error bias we restrict our sample to establishments that change manager origin only once during the period and we also require that each manager is observed more than one year. Estimating the effect without these restrictions produces a somewhat smaller estimate, this is however not significantly different from the fixed effects estimate reported in the table.

${ }^{21}$ Allowing the estimate in column (4) to vary by manager type we found a positive and significant effect (6.8 percentage points) for "Top managers" (the most reliable criteria). For Middle managers [Highest wage] the estimates were $0.046(0.026)$ [0.030 (0.017)].
} 
Table 3 Robustness results

\begin{tabular}{|c|c|c|c|c|c|c|}
\hline & \multicolumn{6}{|c|}{ Dependent variable: $\operatorname{Pr}($ Hire is immigrant) } \\
\hline & $(1)$ & $(2)$ & (3) & $(4)$ & (5) & (6) \\
\hline & $\begin{array}{l}\text { Baseline } \\
\text { ALL }\end{array}$ & $\begin{array}{l}\text { Baseline } \\
\text { No owners }\end{array}$ & $\begin{array}{l}\text { Firm FE } \\
\text { No owners }\end{array}$ & $\begin{array}{c}\text { Est. FE } \\
\text { No owners }\end{array}$ & $\begin{array}{l}\text { Est. Trends } \\
\text { No owners }\end{array}$ & $\begin{array}{l}\text { Est. Trends } \\
\text { No owners }\end{array}$ \\
\hline Immigrant manager & $\begin{array}{c}0.123^{* * *} \\
(0.005)\end{array}$ & $\begin{array}{c}0.051^{* * *} \\
(0.006)\end{array}$ & $\begin{array}{c}0.044 * * * \\
(0.014)\end{array}$ & $\begin{array}{c}0.045^{* * * *} \\
(0.013)\end{array}$ & $\begin{array}{c}0.051 * * * \\
(0.019)\end{array}$ & $\begin{array}{c}0.056 * * * \\
(0.020)\end{array}$ \\
\hline Firm size & Yes & Yes & Yes & Yes & Yes & Yes \\
\hline Mun-Ind-Year & Yes & Yes & Yes & Yes & Yes & Yes \\
\hline Immigrant share ${ }^{\mathrm{A}}$ & Yes & Yes & Yes & Yes $^{A}$ & Yes & Yes \\
\hline Firm-Mun-Ind-Year & - & - & Yes & - & - & - \\
\hline Establishment & - & - & - & Yes & - & - \\
\hline 2 trends & - & - & - & - & Yes & Yes \\
\hline 4 trends & - & - & - & - & - & Yes \\
\hline Observations & 843,085 & 766,983 & 155,085 & 5,504 & 7,706 & 7,706 \\
\hline $\mathrm{R}^{2}$ & 0.272 & 0.195 & 0.111 & 0.241 & 0.075 & 0.076 \\
\hline
\end{tabular}




\subsubsection{Heterogeneity}

We have already established (Table 2) that the impact of manager origin varies across manager types. Here we investigate whether the effects are concentrated to firms/establishments with certain characteristics, or whether manager origin is important across the economy. We use the same baseline specification as before and the results are presented in Table B1. Given the differences between owners and others, we report the estimates including the owners in the estimations (column 1) as well as for the sample containing only the "top", "middle” and "highest wage” managers (column 2).

Overall we find large, positive and significant effects of manager origin on the origin of new hires in establishments of all sizes, in almost all industries and in the private as well as in the public sector. Hence, similarity bias is a general phenomenon and not driven by a particular set of establishments.

There is however substantial heterogeneity in the magnitude of the impact. Manager origin matters more in small firms and small establishments. This pattern is more pronounced when owners are included in the sample but also "top", “middle” and "highest wage” managers have larger impact in the smallest size brackets.

A second interesting result is that effects are larger in the private than in the public sector. Here it is important to note that recruitments in the Swedish public sector are as decentralized and informal as in the private sector, and that previous studies have found discrimination also for public sector jobs in Sweden (see Åslund and Skans, 2007). Hence, there are no institutional barriers preventing public sector managers from hiring workers that are similar to themselves.

In terms of industry, we find that the effect is strongest in "Construction" and "Hotels and Restaurants", but also in "Education” and "Health and Social Work” which are predominantly in the public sector. The effect is also large in "Transport" but this 
estimate is entirely driven by owners. ${ }^{22}$ An additional estimate which stands out is the manufacturing industry where origin does not seem to matter at all.

Table B2 presents results from specifications with four different origin categories instead of two, again relying on the specification of column (4) in Table 2.

Here we estimate four linear probability models, one for the probability of hiring a worker of each of the four origin groups. In all cases we let the reference category be managers of the same origin as the category defining the dependent variable. All regressions control for the workplace composition of employees in the four groups. The results show that managers of all origins are significantly more likely to hire workers from their own group than from any other group, relative to other managers. Crosseffects between natives and Western immigrants are relatively small, suggesting that our main division of the data provides a reasonable baseline. Immigrants from Western countries and from Eastern Europe face rather small differences between same-group managers and managers of other origin. In contrast, native workers as well as NonWestern workers have substantially lower hiring probabilities when the manager does not belong to the same group as themselves. Including the owners in the sample does not alter this pattern.

\subsection{Starting wages}

Similarity between workers and managers could affect starting wages if there are productivity gains from employing individuals that share the same language or business culture. As long as there is some rent sharing, for example due to search frictions, productivity gains should affect starting wages even if the gains are purely match specific. $^{23}$

Table 4 summarizes the main results from traditional wage equations with the log of starting wages as the dependent variable and with age, education and gender as explanatory variables alongside establishment size, own origin and manager origin (see Table B3 for the full table). The richest specification in the last column controls for 2-

\footnotetext{
${ }^{22}$ Whereas native owners are distributed over all detailed industry codes within "Transport” almost all (93 percent) of the immigrant owners are found in the taxi business. (This figure is 37 percent for native owners)

${ }^{23}$ Previous work suggests that productivity gains do affect starting wages, see e.g. Haefke et al (2008).
} 
digit occupation codes, previous wages, and time-invariant unobserved workplace characteristics (establishment fixed effects).

Consistent with previous research we find that immigrant workers receive lower starting wages, even when controlling for detailed level of occupation and previous wages. However, irrespective of specification the coefficient on the interaction (similarity) term is small and insignificant. ${ }^{24}$ Our results thus suggest that immigrants receive lower wages than natives regardless of the manager's origin.

This means that the similarity bias cannot be understood in a pure productivity context unless wages are independent of match-specific productivity. Interestingly, there is no additional wage premium from sharing the same country of origin as the manager (column 4) This variable could be viewed as an indicator for sharing the same language and culture, and we would therefore expect a positive estimate if productivity gains were an important explanation for the similarity bias in hires.

Table 4 Starting wages

\begin{tabular}{|c|c|c|c|c|}
\hline & \multicolumn{4}{|c|}{ Dependent variable: Log monthly starting wage } \\
\hline & (1) & $(2)$ & $(3)$ & $(4)$ \\
\hline Both immigrant & $\begin{array}{c}0.013 \\
(0.013)\end{array}$ & $\begin{array}{c}0.009 \\
(0.011)\end{array}$ & $\begin{array}{c}0.012 \\
(0.011)\end{array}$ & $\begin{array}{c}0.017 \\
(0.019)\end{array}$ \\
\hline Both immigrants from same country ${ }^{A}$ & -- & -- & -0.017 & -0.025 \\
\hline Immigrant manager & $\begin{array}{c}0.012 \\
(0.009)\end{array}$ & $\begin{array}{c}0.008 \\
(0.008)\end{array}$ & $\begin{array}{c}0.008 \\
(0.008)\end{array}$ & $\begin{array}{c}0.011 \\
(0.010)\end{array}$ \\
\hline Immigrant hire & $\begin{array}{c}-0.060^{\star * *} \\
(0.002)\end{array}$ & $\begin{array}{c}-0.048^{\star * *} \\
(0.002)\end{array}$ & $\begin{array}{c}-0.048^{\star * *} \\
(0.002)\end{array}$ & $\begin{array}{c}-0.022^{\star \star *} \\
(0.003)\end{array}$ \\
\hline Establishment dummies & Yes & Yes & Yes & Yes \\
\hline Occupational dummies (2-digit) & - & Yes & Yes & Yes \\
\hline Wage in prev. job & - & - & - & Yes \\
\hline Observations & 205,811 & 205,811 & 205,811 & 71311 \\
\hline $\mathrm{R}^{2}$ & 0.661 & 0.723 & 0.723 & 0.892 \\
\hline
\end{tabular}

Notes. ${ }^{*},{ }^{* *}$ and ${ }^{* \star *}$ denote statistical significance at 10/5/1 percent level respectively. Robust standard errors are clustered at the establishment level. The model compares the starting wages of individuals within the same establishment controlling for age, education, gender, establishment size, worker origin, and manager origin. The sample consists of all workplaces in the public sector as well as a sample form the public sector. There is thus an underrepresentation of the private sector in these estimations. Estimating the effect separately by sector does not alter the main conclusions.

A Table A1 provides a list of countries.

\footnotetext{
${ }^{24}$ As expected, wages at entry are higher for males and are increasing in age, the level of education and in establishment size.
} 


\subsection{Separations}

Next we explore whether there are differences in employment duration depending on worker and manager similarity. We estimate the probability of separating using a dataset consisting of all workers in establishments with less than 50 employees in the year 2000. The model accounts for establishment fixed effects (thus implicitly also manager origin since the data are cross-sectional), worker origin, worker human capital and tenure at the establishment. The main variable of interest is the interaction term between the origin of the manager and the worker, which measures the effect of similar origin on the probability of job separation.

To conserve space Table 5 only reports the coefficients of primary interest, i.e. interaction between being immigrant and having an immigrant manager and the baseline effect of being immigrant. ${ }^{25}$ As shown by the first column in the table workers are less likely to leave when the manager has a similar origin as the worker. Evaluated at the sample mean, the estimate implies 22 percent higher probability of separation under dissimilar management.

Unfortunately, we cannot distinguish between voluntary quits and firings. Results presented in the second panel of Table 5, however, show that the impact is unlikely to be driven by downsizing firms: restricting the sample to establishments which hired at least one new worker in 2001 yields very similar results.

As in many other countries newly hired workers in Sweden are subject to a probation period in which they are not protected against firing at will by the employer. The Swedish employment protection legislation (EPL) is particularly focused on protecting tenured workers from layoffs (see e.g. OECD, 2004) and considers all employees with three years of tenure as being employed on an open-ended contract. Firms cannot lay off protected workers unless they are fired for cause, which is an extremely rare event due to very strict legal requirements (OECD, 2004), or if the firm is downsizing. In columns (2)-(3) we utilize this institutional feature and estimate the above model separately for workers who are protected and unprotected of EPL respectively (i.e. with less than or at

\footnotetext{
${ }^{25}$ All control variables show the expected signs. The probability to quit decreases with age and tenure, male workers are more likely to quit than females.
} 
least 3 years of tenure). Panel $B$ also restricts the analysis to firms that hire after the separation.

Table 5 OLS estimates of origin similarity on the probability of separation

\begin{tabular}{lccc}
\hline & \multicolumn{3}{c}{ Dependent variable: Pr(Quit) } \\
\hline Sample: & $(1)$ & $(2)$ & $(3)$ \\
Panel A: All establishments & ALL & Tenure $1-2$ years & Tenure > 2 years \\
Worker and manager & $-0.037^{\star}$ & $-0.104^{\star *}$ & 0.016 \\
immigrants & $(0.020)$ & $(0.044)$ & $(0.024)$ \\
& & & \\
Worker immigrant & $0.039^{\star \star *}$ & $0.058^{\star \star *}$ & $0.015^{\star *}$ \\
& $(0.004)$ & $(0.008)$ & $(0.005)$
\end{tabular}

Manager immigrant

Captured by establishment fixed effects

\begin{tabular}{lccc} 
Observations & 435,142 & 107,830 & 327,312 \\
$\mathrm{R}^{2}$ & 0.159 & 0.301 & 0.171 \\
\hline Panel B: Establishments that hired next year: & $-0.043^{\star *}$ & $-0.103^{\star *}$ & -0.002 \\
Worker and manager & $(0.021)$ & $(0.044)$ & $(0.024)$ \\
immigrants & & & \\
& $0.038^{\star \star *}$ & $0.058^{\star \star *}$ & $0.013^{*}$ \\
Worker immigrant & $(0.004)$ & $(0.009)$ & $(0.005)$
\end{tabular}

Manager immigrant

Captured by establishment fixed effects

\begin{tabular}{lccc} 
Observations & 380,002 & 90,939 & 289,063 \\
$\mathrm{R}^{2}$ & 0.143 & 0.296 & 0.154 \\
\hline Est. dummies & Yes & Yes & Yes \\
Controls for tenure & Yes & Yes & Yes \\
Individual controls & Yes & Yes & Yes
\end{tabular}

Notes: Each column represents a separate regression. ${ }^{*},{ }^{* \star}$ and ${ }^{* * \star}$ denote statistical significance at 10/5/1 percent level respectively. Standard errors robust for serial correlation at the establishment level are shown in parentheses. The estimated model is a linear probability model where the dependent variable indicates whether the individual quit from the establishment in 2000. Panel A uses all establishments where at least one individual quit in the specific year; Panel $B$ is restricted to those establishments that hired at least one worker the following year. All regressions include establishment fixed effects, and controls for tenure. We also include gender, education dummies, age and age ${ }^{2}$. Note that the main effect of manager ethnicity is captured by the establishment fixed effects (1 year-no variation within establishments).

These estimates reveal that the effect on separations is concentrated to workers who are unprotected by EPL - the point estimate for the sample of tenured workers in establishments that recruit (which prohibit layoffs due to downsizing) is 0.002 and highly insignificant despite the large number of observations. There are at least two possible explanations for this pattern: (i) actions by the managers are driving the separations (i.e. dissimilar workers are fired more often), and these actions are only feasible during probation; (ii) workers are more likely to quit voluntarily under a dissimilar manager but only when the value of the job is relatively low (i.e. giving up a position covered by EPL is too high a cost for not working with a non-preferred 
manager). In any case these results are consistent with origin bias being strongest when the costs for dissolving the match are relatively low. ${ }^{26}$

\subsection{Recruitments of past colleagues}

What explains the observed hiring bias? The non-existent impact of manager origin on starting wages is inconsistent with a pure productivity explanation unless all matchspecific rents are taken by the employer. The fact that immigrant managers tend to hire also immigrant workers from other parts of the world further signals that there is room for alternative explanations.

Information asymmetries or networks may be important; either because managers find it difficult to screen workers who are dissimilar to themselves or because managers prefer to hire workers who are known to them from before. If immigrant managers, for some reason, know more immigrant workers than native managers do, similarity may matter for this reason alone.

Table A4 shows the origin of all past colleagues for recently hired managers and workers. Immigrant managers have much more previous experiences of working with immigrants than native managers have. Thus, their professional networks are likely to involve many more immigrant workers. If these (or other similarly segregated) networks are important sources of information for future recruitments, then segregation may self-propagate. In fact, previous research (e.g. Granovetter 1995) does suggest that former colleagues account for a large portion of jobs found through personal contacts. Cingano and Rosalia (2008) also show that the employment rate of former co-workers significantly shortens unemployment duration for recently displaced workers.

Our data include a long panel of individual working histories, which allows us to analyse how managers recruit when they hire former colleagues and estimate whether there is a similarity bias also in these cases. This setting isolates within-network differences at the same time as information asymmetries should be less of a concern (assuming that work-related information is revealed when working together).

\footnotetext{
${ }^{26}$ Splitting the sample according to manager origin shows that this same origin bias is primarily driven by immigrant workers being more likely to quit under western management.
} 
Our model estimates the impact of similarity on the probability of being hired by a former co-worker who is now manager at a new establishment. The model includes a fixed effect for each establishment where a manager has worked (using data up to 20 years back) which means that we estimate the probability that each single colleague (at the old workplace) is recruited to the establishment where the manager currently works. An important feature of the model is that we, by the inclusion of the fixed effect at the old establishment, capture all unobserved differences that are shared between workers at the past workplace $k$ at the time of past interaction (s). The sample restriction requires variation within each fixed effect group, which in practice means that someone (but not everyone) has to be hired from each past establishment, and also that there are workers of different origin present. The data thus include all workers at past establishments meeting these criteria. Formally, we estimate the following model:

$$
E_{i, k s, j t}=\gamma M_{k s, j t}^{i m}+\lambda W_{i, k s, j t}^{i m}+\delta M_{k s, j t}^{i m} * W_{i, k s, j t}^{i m}+X_{i, k s, j t} \beta+\eta_{k s}+\varepsilon_{j t}
$$

where $E$ is a dummy taking the value one if worker $i$ in establishment $k$ in year $s$ is hired to establishment $j$ in year $t$. $W$ is an indicator for the origin of the worker. $M$ is an indicator for an immigrant manager in establishment $j$ at time $t$ (who worked in establishment $k$ at time $s$ ) and $\eta$ is the fixed effect for each set of previous coworkers (i.e. establishment*year).

The coefficient of interest $\delta$ measures whether similarity with the (future) manager increases the probability to be hired relative to other workers in the (past) establishment. ${ }^{27}$ A positive estimate of $\delta$ would indicate that managers are more likely to bring with them workers of similar origin regardless of their baseline probability to follow and the composition of the network (sometimes denoted as the "inbreeding bias”). By contrast, if the similarity bias is driven by informal hiring and origin

\footnotetext{
${ }^{27}$ The strategy is similar to the network studies of Bayer et al (2008) who look at whether individuals are more likely to work together if they live in the same block than individuals who live in the same census tract but not in the same block. The analogue is that we treat the previous workplace as the census tract and estimate whether a worker who belongs to the same ethnicity (block) is more likely to follow the manager than a worker belonging to the same previous establishment (tract) but not to the same ethnicity. Kramarz and Skans (2007) use a similar strategy to study
} 
segregation in past networks then we expect there to be little remaining impact of origin similarity when accounting for the differential composition of these networks (past coworkers). Hence by looking at the estimate of $\delta$ we may be able to infer whether the impact of similarity with the manager remains when information asymmetries are substantially reduced. Among all new hires in our sample during the period 1997-2005, 4 percent (around 39,000) had worked at the same establishment as the hiring manager for at least one year in the period from 1985 and up to the hire. Table 6 presents the estimates.

Table 6 Fixed effects estimates of the effect of origin among former colleagues

\begin{tabular}{|c|c|c|c|}
\hline \multicolumn{4}{|c|}{ Dependent variable: $\operatorname{Pr}$ (Follow from old workplace) } \\
\hline & (1) & (2) & (3) \\
\hline Sample: & ALL & ALL & Same skill group \\
\hline $\begin{array}{l}\text { Worker and manager } \\
\text { immigrants }\end{array}$ & $\begin{array}{l}0.048^{\star \star *} \\
(0.007)\end{array}$ & $\begin{array}{l}0.020^{* \star *} \\
(0.007)\end{array}$ & $\begin{array}{l}0.016^{\star *} \\
(0.007)\end{array}$ \\
\hline Same im. source country & - & $\begin{array}{c}0.098^{\star * *} \\
(0.015)\end{array}$ & $\begin{array}{c}0.094^{\star \star \star} \\
(0.016)\end{array}$ \\
\hline Worker immigrant & $\begin{array}{l}-0.002 \\
(0.003)\end{array}$ & $\begin{array}{l}-0.002 \\
(0.003)\end{array}$ & $\begin{array}{l}-0.0002 \\
(0.003)\end{array}$ \\
\hline Manager immigrant & \multicolumn{3}{|c|}{ Captured by fixed effects } \\
\hline $\begin{array}{l}\text { Establishment fixed effects } \\
\text { Est.*Education fixed effects } \\
\text { Observations }\end{array}$ & $\begin{array}{c}\text { Yes } \\
\text { No } \\
1,124,036\end{array}$ & $\begin{array}{c}\text { Yes } \\
\text { No } \\
1,124,036\end{array}$ & $\begin{array}{c}\text { Yes } \\
\text { Yes } \\
518,454\end{array}$ \\
\hline $\mathrm{R}^{2}$ & 0.209 & 0.209 & 0.157 \\
\hline $\begin{array}{l}\text { Notes: Each column represe } \\
10 / 5 / 1 \text { percent level respecti } \\
\text { are shown in parentheses. T } \\
\text { individual followed the mana } \\
\text { "follower". The last column } \\
\text { educational level is a dummy } \\
\text { some college education. The } \\
\text { establishments. There are } 20 \\
1,242(83,326) \text { cases a previ }\end{array}$ & $\begin{array}{l}\text { parate regre } \\
\text { andard error } \\
\text { ple includes } \\
\text { new workpl } \\
\text { he within es } \\
\text { the value or } \\
\text { includes al } \\
\text { 104,023) ol } \\
\text { worker was }\end{array}$ & $\begin{array}{l}d{ }^{\star \star \star} \text { denote } \\
\text { erial correlati } \\
\text { establishme } \\
\text { odel estima } \\
\text { רd education } \\
\text { dual has high } \\
\text { s well as all } \\
\text { ider immigra } \\
\text { nigrant (nati }\end{array}$ & $\begin{array}{l}\text { significance at } \\
\text { stablishment level } \\
\text { at least one } \\
\text { bability to be the } \\
\text { ect where the } \\
\text { defined as at least } \\
\text { at the previous } \\
\text { management, in } \\
\text { er. }\end{array}$ \\
\hline
\end{tabular}

The results suggest that workers are more likely to be hired by former colleagues, now managers, if they share the same broad origin. As indicated by the coefficient "Same immigrant source country" the effect is strongest when immigrant workers and managers are from the same source country, but there are also significant cross-group 
effects. One potential concern is that there can be skill differences between immigrants and natives in the previous workplace driving these correlations. However, it is reassuring to find that this result holds if we condition on human capital of the competitors, by including dummies for establishment-level-of-education cells in the regressions (column (3)). The idea is then that the later manager only considered former coworkers of similar skill as the one(s) actually recruited.

\section{Discussion}

We examine the impact of manager origin on the origin composition of hires. Previous research reveals ethnic discrimination in the hiring procedure and documents substantial segregation by ethnicity/origin across establishments. But empirical evidence on the influence of managers in explaining these phenomena is scarce.

Our results provide strong evidence that manager origin does matter for who gets hired. Establishments disproportionately often hire workers who share background with the manager. This pattern holds in a large set of specifications, utilizing variation in several dimensions to control for observed and unobserved characteristics and trends, suggesting that we actually capture a causal effect of manager origin. These results are consistent with racial and ethnic hiring biases documented in single firm studies by Giuliano et al. (2009) and Bandiera et al. (2009).

Although it is hard to pin down exactly why managers are more likely to hire their ethnic peers, our results do leave some suggestive evidence of the mechanisms at work. Two observations speak against the possibility that managers hire similar workers for efficiency reasons. The first is that immigrant managers are also more likely to hire immigrants of other descent than their own, whereas efficiency gains are likely to come with e.g. a common language. Furthermore, we find no evidence that similarity affects entry wages, not even when managers and hires come from the same country. Thus, a pure productivity story can only explain the results if the employer extracts all matchspecific productivity gains and if immigrant workers are more productive also when hired by immigrant managers whose language they do not speak.

graduate from the same school, class, and field of study. 
Instead we interpret our findings as favoring an explanation based on networks or information asymmetries. Most notably, there is no impact of ethnic similarity when native managers, who make up the vast majority of managers, recruit from a known pool of candidates (previous coworkers). This suggests that native managers are unbiased in a setting where information asymmetries are reduced through previous interaction. An alternative interpretation is that they are still biased, but their behavior is counteracted by immigrant workers being more inclined to follow former co-workers. Since this latter explanation requires that the two effects cancel out exactly, we lean towards the former.

Some of our findings point in a somewhat different direction than previous studies. In contrast to Giuliano et al. (forthcoming), our results regarding separation rates indicate that at least part of the effects are driven by actions taken by the managers rather than the workers. It seems unlikely that Non-Western immigrants (who have the lowest job finding rates) would be willing to leave voluntarily due to the origin of their manager, especially since the separations only occur as long as workers are unsheltered by employment protection legislation. Another finding implicating that manager behavior matters is that the impact on recruitment patterns is larger when the manager has a higher financial stake in the outcomes, e.g. at firms in the for-profit sector and in owner-managed establishments. The latter finding is also in some contrast to Bandiera et al. (2009) who conclude that stronger financial incentives for managers reduce the ethnic bias in their decisions.

These differences may partly stem from the fact that our data are drawn from a much more general labor market. Bad hiring decisions may carry a lower cost at the high turnover jobs studied previously. This difference can also be reinforced by a higher union coverage and more stringent employment protection legislation in Sweden than in the US or the UK. It is also conceivable that the uncertainty about worker productivity is greater at the overall labor market than e.g. in the case of fruit pickers studied in Bandiera et al. (2009). A conjecture consistent with the results is that similarity may be a pure consumption good under perfect information, but primarily a tool for reducing information asymmetries when uncertainty about worker productivity is high and when recruitments are difficult to reverse. 
Overall, our results indicate that lack of access to "key players" at the labor market can explain some of the difficulties faced by workers of Non-Western descent. Increasing the representation of immigrants in managerial positions could therefore improve other immigrants' employment prospects. This implies that promoting the careers of already employed immigrants may be an important complement to current integration policies which nearly exclusively focus on getting the non-employed into work. 


\section{References}

Ahmed, A. M. (2007). "Group identity, social distance and intergroup bias", Journal of Economic Psychology 28(3), pp. 324-337.

Åslund O and O N Skans (2007) "Do anonymous job application procedures level the playing field?”, IFAU Working Paper 2007:31.

Åslund O and O N Skans (2009) "Will I See You at Work: Ethnic Workplace Segregation in Sweden 1985-2002”, forthcoming in Industrial and Labor Relations Review.

Bandiera O, I Barankay and I Rasul (2009) "Social Connections and Incentives in the Workplace: Evidence form Personnel Data”, Econometrica 77(4), pp. 1003-1337

Bayer P, S Ross and G Topa (2008), "Place of Work and Place of Residence: Informal Hiring Networks and Labor Market Outcomes”, Journal of Political Economy 116(6), pp. 1150-1196.

Becker G. S (1957) The Economics of Discrimination”, Chicago University Press, Chicago

Bertrand M and S Mullainathan (2004), “Are Emily and Greg More Employable than Lakisha and Jamal? A Field Experiment on Labor Market Discrimination” American Economic Review, Vol. 94, No. 4, pp. 991-1013

Calvo-Armengol T and M O Jackson (2004), "The Effects of Social Networks on Employment and Inequality”, American Economic Review, vol. 94, no. 3, pp. 426454

Carduso A R and R Winter-Ebmer (2007) "Mentoring and Segregation: Female-Led Firms and Gender Wage Policies”, IZA DP No. 3210

Carlsson M, and D Rooth (2007) "Evidence of Discrimination in the Swedish Labor Market Using Experimental Data”, Labour Economics 14(4), pp. 716-729.

Carrington W J. and K R. Troske (1995) “Gender Segregation in Small Firms”, The Journal of Human Resources, Vol 30:3, pp. 503-533 
Carrington W J., K R. Troske (1998) “Interfirm Segregation and the Black/White Wage Gap”, Journal of Labor Economics, Vol 16:2

Cingano F and A Rosalia (2008) "People I know: Job Search and Social Networks", CEPR Discussion Paper No. 6818.

Currarini S, M O. Jackson and P Pin (2009) “An Economic Model of Friendship: Homophily, Minorities, and Segregation”, Econometrica 77(4), pp.1003-1045

den Butter F. A. G., E Masurell, and R H.J. Mosch (2004) "The Economics of Co Ethnic Employment”, Tinbergen Institute Discussion Paper 2004-027/3.

Dustmann C, A Glitz and U Schönberg (2009) "Referral-based Job Search Networks”, Mimeo, October, 2009.

Edin P-A and P Fredriksson (2000),"LINDA - Longitudinal INdividual DAta for Sweden”, Working Paper 2000:19, Department of Economics, Uppsala University.

Eriksson, S., "Arbetsutbud och sysselsättning bland personer med utländsk bakgrund: En kunskapsöversikt", Ds 2007:4, Fritzes, Stockholm

Fershtman C and U Gneezy (2001) "Discrimination in a Segmented Society: An Experimental Approach” Quarterly Journal of Economics, February 2001, Vol. 116, No. 1, pp. 351-377

Giuliano L, D I Levine and J Leonard (2009) "Manager Race and the Race of New Hires”, Journal of Labor Economics Oktober, Vol. 27, No. 4, pp. 589-631

Giuliano L, D I Levine and J Leonard (forthcoming) "Racial Bias in the ManagerEmployee Relationship: An Analysis of Quits, Dismissals, and Promotions at a Large Retail Firm”, Paper iirwps-178-09, Journal of Human Resources.

Granovetter M (1973) "The Strength of Weak Ties", American Journal of Sociology 78 (6), pp. 1360-1380.

Haefke C, M Sonntag, T van Rens (2008) "Wage Rigidity and Job Creation” IZA Discussion Paper No. 3714 
Hellerstein J K, M McInerney and D Neumark (2008b) ”Neighbors and Co-Workers: The impact of Residential Labor Market Networks”, NBER Working Paper No. 14201.

Hellerstein J K., and D Neumark (2008) "Workplace Segregation in the United States: Race, Ethnicity, and Skill”, Review of Economics and Statistics 90(3), pp. 459-477.

Hellerstein, Judith K., David Neumark, and Melissa McInerney (2009), "Spatial Mismatch, Immigrant Networks, and Hispanic Employment in the United States”, NBER Working Paper No. 15398.

Hellerstein, Judith K., David Neumark, and Melissa McInerney (2008a) "Spatial Mismatch vs. Racial Mismatch?”, Journal of Urban Economics, Vol. 64, No. 2, pp. 467-79.

Hultin M and R Szulkin (2003) "Mechanisms of Inequality, Unequal Access to Organizational Power and the Gender Wage Gap”, European Sociological Review 19, pp. 143-159.

Ioannides M Y and L D Loury (2004) “Job Information, Neighborhood Effects and Inequality”, Journal of Economic Literature 42(4), pp. 1056-1093

Kramarz F and Skans O N (2007) "With a little help from my...parents? Family Networks and Youth Labor Market Entry”, Crest Working paper, 2007

Lazear EP (1999) “Culture and Language”, Journal of Political Economy 107(6), pp. 95-126.

McPherson M, L Smith-Lovin, J M Cook (2001) "Birds of a Feather: Homophily in Social Networks” Annual Review of Sociology Vol 27, pp. 415-444

Mella O and I Palm (2009) “Mångfaldsbarometern 2009”, Department of Sociology, Uppsala University, Uppsala.

Montgomery J D (1991) “Social Networks and Labour-Market Outcomes: Toward an Economic analysis”, American Economic Review, 81(5), 1407-18.

Munshi K (2003) "Networks in the Modern Economy: Mexican Migrants in the U. S. Labor Market”, Quarterly Journal of Economics Vol. 118, No. 2, Pages 549-599. 
OECD (2004) OECD Employment Outlook 2004.

Skans O N, P-A Edin and B Holmlund (2009) "Wage dispersion between and within plants: Sweden 1985-2000" in Lazear E and K Shaw (eds) The Structure of Wages: An International Comparison, NBER and University of Chicago Press.

Stoll M A, S Raphael and H J. Holzer, (2004) "Black Job Applicants and the Hiring Officer's Race”, Industrial and Labor Relations Review, Vol 57 Issue 2 Article 6 


\section{Appendix A, Descriptives}

Table A1 Countries and regions

\begin{tabular}{|c|c|}
\hline Region & Countries included \\
\hline \multicolumn{2}{|l|}{ "Natives" } \\
\hline Native & 0- Sweden \\
\hline \multirow[t]{8}{*}{ Western } & 1-Finland \\
\hline & 2-Denmark \\
\hline & 3-Norway+ Iceland \\
\hline & $4-G B+$ Ireland \\
\hline & 5-Germany \\
\hline & $\begin{array}{l}\text { 6-Mediterr. Europe (Greece + Italy + Spain + Portugal + the Vatican + Monaco + } \\
\text { Malta + San Marino) }\end{array}$ \\
\hline & $\begin{array}{l}\text { 7-Other Europe (Andorra + Belgium + France + Liechtenstein + Luxemburg + the } \\
\text { Netherlands + Switzerland + Austria) }\end{array}$ \\
\hline & 8-US + Canada \\
\hline \multicolumn{2}{|l|}{ “Immigrants" } \\
\hline \multirow[t]{6}{*}{ Eastern Europe } & 9-Bosnia-Herzegovina \\
\hline & 10-Former Yugoslavia (Yugoslavia + Croatia + Macedonia + Slovenia) \\
\hline & 11-Poland \\
\hline & 12-The Baltic states (Estonia + Latvia + Lithuania) \\
\hline & 13-Eastern Europe 1 (Rumania + The former USSR + Bulgaria + Albania) \\
\hline & 14-Eastern Europe 2 (Hungary + The former Czechoslovakia) \\
\hline \multirow[t]{13}{*}{ Non-Western, Non-Europe } & 15-Mexico and Central America \\
\hline & 16-Chile \\
\hline & $\begin{array}{l}\text { 17-Other South America (Argentina + Bolivia + Peru + Colombia + Uruguay + } \\
\text { Ecuador + Guyana + Paraguay + Surinam + Venezuela) }\end{array}$ \\
\hline & 18-African Horn (Ethiopia + Somalia +Sudan + Djibouti), \\
\hline & $\begin{array}{l}\text { 19- North Africa + Middle East (Lebanon + Syria + Morocco + Tunisia + Egypt + } \\
\text { Algeria + Israel + Palestine + Jordan + South Yemen + Yemen + the United Arab } \\
\text { Emirates + Kuwait + Bahrain + Qatar + Saudi Arabia + Cyprus })\end{array}$ \\
\hline & 20- Other African (all African countries not included elsewhere) \\
\hline & 21-Iran \\
\hline & 22-Iraq \\
\hline & 23-Turkey \\
\hline & 24-East Asia (Japan + China + Korea + Hong Kong + Taiwan) \\
\hline & $\begin{array}{l}\text { 25-Southeast Asia (Vietnam + Thailand + the Philippines + Malaysia + Laos + } \\
\text { Burma + Indonesia + Singapore) }\end{array}$ \\
\hline & $\begin{array}{l}\text { 26-Other Asia (Sri Lanka + Bangladesh + India + Afghanistan + Pakistan + Brunei + } \\
\text { Bhutan + Kampuchea + the Maldives + Mongolia + Nepal + Oman + Sikkim) }\end{array}$ \\
\hline & 27-Oceania (Australia + New Zealand etc...) \\
\hline
\end{tabular}


Table A2 Share of total number of establishments in the economy according to establishment size

\begin{tabular}{lcccc}
\hline Sample: & ALL & Public & Private & Private multiple \\
\hline $1-9$ & 0.37 & 0.93 & 0.35 & 0.48 \\
$10-49$ & 0.50 & 0.98 & 0.27 & 0.60 \\
$50-199$ & 0.75 & 0.98 & 0.53 & 0.69 \\
$200-499$ & 0.86 & 0.97 & 0.81 & 0.88 \\
$500-$ & 0.96 & 0.98 & 0.95 & 0.98 \\
\hline
\end{tabular}

Notes: The table shows the number of establishments in our sample as a share of the total number of establishments in the economy. The sampling is stratified by firm size with the sampling probabilities $3 \%, 12 \%, 41 \%, 70 \%$ and $100 \%$ for the firm size intervals reported in the table respectively. The share of establishments with more than 500 employees and the share of public establishments should be $100 \%$. However since the figure are based on authors calculations by dividing the number of establishments where we have information on wages with the total number of establishments in the nation wide data some of the establishments are missing for other reasons than sampling. 
Table A3 Sample statistics for robustness specifications

\begin{tabular}{|c|c|c|c|c|}
\hline & (1) & $(2)$ & (3) & (4) \\
\hline \multirow[t]{2}{*}{ Sample } & $A L L$ & $A L L$ & Firm FE & Est.FE \\
\hline & & No owners & sample & sample \\
\hline \multicolumn{5}{|l|}{ Manager Characteristics } \\
\hline Owner & 0.09 & - & 0.00 & 0.02 \\
\hline Top Manager & 0.14 & 0.15 & 0.20 & 0.16 \\
\hline Middle Manager & 0.24 & 0.26 & 0.38 & 0.21 \\
\hline Highest wage & 0.53 & 0.58 & 0.41 & 0.61 \\
\hline \multirow[t]{2}{*}{ Sample } & $A L L$ & $A L L$ & Firm FE & Est. FE \\
\hline & & No owners & No owners & No owners \\
\hline \multicolumn{5}{|l|}{ Establishment characteristics } \\
\hline Establishment size & 24.3 & 25.6 & 24.6 & 25.5 \\
\hline Non-western share in mun-ind & 0.06 & 0.05 & 0.05 & 0.10 \\
\hline New Hires/Year & 5.0 & 5.2 & 4.8 & 6.5 \\
\hline [Sd] & [3.74] & [3.77] & [3.59] & [4.61] \\
\hline \multicolumn{5}{|l|}{ Industry } \\
\hline Agriculture, hunting and forestry & 2.1 & 0.9 & 1.1 & 0.3 \\
\hline Fishing & 0.0 & 0.0 & 0.0 & 0.0 \\
\hline Mining and quarrying & 0.0 & 0.0 & 0.0 & 0.0 \\
\hline Manufacturing & 3.1 & 2.9 & 5.1 & 1.3 \\
\hline Electricity, gas and water supply & 0.6 & 0.7 & 0.4 & 0.0 \\
\hline Construction & 3.9 & 3.0 & 4.5 & 0.6 \\
\hline Wholesale and retail sale & 14.2 & 13.9 & 39.7 & 18.0 \\
\hline Hotels and restaurants & 3.0 & 1.6 & 3.0 & 2.9 \\
\hline Transport, storage and communication & 5.3 & 4.5 & 5.1 & 1.7 \\
\hline Financial intermediation & 3.5 & 3.8 & 16.4 & 2.0 \\
\hline Real Estate, renting and business activities & 6.7 & 6.4 & 12.2 & 4.3 \\
\hline Public adm. and defense & 4.8 & 5.3 & - & 4.5 \\
\hline Education & 17.1 & 18.6 & 3.0 & 13.3 \\
\hline Health and Social work & 28.0 & 31.6 & 5.8 & 46.1 \\
\hline $\begin{array}{l}\text { Other community, social and personal } \\
\text { service activities }\end{array}$ & 6.7 & 6.9 & 3.8 & 5.1 \\
\hline Observations & 843,085 & 766,983 & 155,085 & 5,504 \\
\hline
\end{tabular}

Notes: Column (i) reports sample characteristics for the overall sample of hires whereas column (2), (3) and (4) shows the characteristics for the samples used in the robustness specifications reported in Table 3 in the main text. The level of observation is the individual and hence the table shows the fraction of new hires in each category. The four samples correspond to 95,910 (1), 68,307 (2), 17,706 (3) and 372 (4) establishments respectively. 
Table A4 Share of immigrant co-workers in past five years (for newly hired managers and individuals in 2005)

\begin{tabular}{lccc}
\hline Sample: & ALL & Immigrant & Native \\
\hline Managers & 0.06 & 0.28 & 0.05 \\
(Sd) & $(0.09)$ & $(0.29)$ & $(0.06)$ \\
Hires & 0.08 & 0.24 & 0.07 \\
(Sd) & $(0.11)$ & $(0.21)$ & $(0.07)$ \\
\hline
\end{tabular}

Notes: The figures in the table were obtained by tracking the previous establishments of all newly hired workers and managers in 2005 and calculating the average share of immigrants in these establishments. 


\section{Appendix B, Additional results}

Table B1 Effects of manager origin on hires and quits in various subsamples

\begin{tabular}{|c|c|c|c|c|}
\hline & \multicolumn{4}{|c|}{ Equation 1} \\
\hline & \multicolumn{2}{|c|}{ ALL } & \multicolumn{2}{|c|}{ No owners } \\
\hline & estimate & se & estimate & se \\
\hline Main effect & $0.123^{* * *}$ & & $0.051^{* \star \star}$ & 0.005 \\
\hline \multicolumn{5}{|l|}{ Establishment size } \\
\hline $2-9$ & $0.244^{\star \star \star}$ & 0.008 & $0.078 * \star \star$ & 0.015 \\
\hline $10-19$ & $0.121^{\star \star \star}$ & 0.008 & $0.048 * \star \star$ & 0.010 \\
\hline $20-29$ & $0.068^{\star \star \star}$ & 0.010 & $0.056 * \star \star$ & 0.012 \\
\hline $30-39$ & 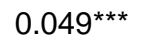 & 0.013 & $0.032^{\star \star \star}$ & 0.012 \\
\hline $40-49$ & $0.053^{\star \star \star}$ & 0.013 & $0.047^{* \star *}$ & 0.013 \\
\hline \multicolumn{5}{|l|}{ Sector } \\
\hline Public & $0.038^{\star \star \star}$ & 0.007 & $0.038^{\star * *}$ & 0.007 \\
\hline Private - single establishment firm & $0.218^{\star \star \star}$ & 0.013 & 0.038 & 0.034 \\
\hline Private - multiple establishment firm & $0.056^{\star \star \star}$ & 0.013 & $0.056^{\star \star \star}$ & 0.013 \\
\hline \multicolumn{5}{|l|}{ Firm size } \\
\hline Private - firm with less than 10 workers & $0.308^{\star \star \star}$ & 0.012 & $0.183^{\star * \star}$ & 0.050 \\
\hline Private - firm with $10-49$ workers & $0.194^{\star \star \star}$ & 0.013 & $0.121^{\star \star \star}$ & 0.032 \\
\hline Private - firm with 50-99 workers & 0.071 & 0.047 & 0.080 & 0.048 \\
\hline Private - firm with $100+$ workers & $0.046^{\star \star \star}$ & 0.012 & $0.050 * \star \star$ & 0.013 \\
\hline \multicolumn{5}{|l|}{ Industry ${ }^{(1)}$} \\
\hline Agriculture, hunting and forestry & $0.212^{\star \star \star}$ & 0.059 & 0.101 & 0.066 \\
\hline Manufacturing & 0.038 & 0.046 & -0.008 & 0.051 \\
\hline Construction & $0.279 * \star \star$ & 0.042 & $0.161^{\star \star \star}$ & 0.055 \\
\hline Wholesale and retail sale & $0.157^{\star \star \star}$ & 0.013 & $0.048^{\star \star \star}$ & 0.012 \\
\hline Hotels and restaurants & $0.209 * \star \star$ & 0.012 & $0.113^{\star \star \star}$ & 0.028 \\
\hline Transport, storage and communication & $0.240^{\star \star \star}$ & 0.017 & 0.026 & 0.023 \\
\hline Financial intermediation & 0.018 & 0.018 & 0.020 & 0.017 \\
\hline Real Estate, renting and business activities & $0.163^{\star \star \star}$ & 0.020 & $0.045^{\star}$ & 0.026 \\
\hline Compulsory social security & $0.073^{\star \star \star}$ & 0.027 & $0.075^{\star \star}$ & 0.027 \\
\hline Education & $0.072^{\star \star \star}$ & 0.016 & $0.075^{\star \star \star}$ & 0.016 \\
\hline Health and Social work & $0.042^{\star \star \star}$ & 0.008 & $0.037^{* * *}$ & 0.008 \\
\hline Other community, social and personal services & $0.085^{\star \star \star}$ & 0.019 & $0.042^{\star *}$ & 0.020 \\
\hline
\end{tabular}

Notes: ${ }^{*}{ }^{\star \star}$ and ${ }^{\star \star \star}$ denote statistical significance at 10/5/1 percent level respectively. Standard errors robust for serial correlation at the establishment level are shown in parentheses. The table reports results from six integrated regressions (per outcome). Columns (1) and (2) report the heterogeneous effects with and without owners respectively. All regressions control for the share of immigrants at the establishment, establishment size dummies of ten employee intervals as well as dummies for municipality-industry-year. (1) Estimates are not shown for industries with less than 1 percent of all hires; see the first column of Table A4. 
Table B2 OLS estimates disaggregated by origin groups (No owners included)

\begin{tabular}{|c|c|c|c|c|}
\hline & \multicolumn{4}{|c|}{ Hire ethnicity } \\
\hline & (1) & (2) & (3) & (4) \\
\hline & Native & $\begin{array}{l}\text { Non-native } \\
\text { Western }\end{array}$ & $\begin{array}{l}\text { Eastern } \\
\text { European }\end{array}$ & $\begin{array}{l}\text { Immigrant, Non- } \\
\text { European }\end{array}$ \\
\hline \multicolumn{5}{|l|}{ Manager origin } \\
\hline Native & $\begin{array}{l}- \\
-\end{array}$ & $\begin{array}{l}-0.013^{\star * *} \\
(0.002)\end{array}$ & $\begin{array}{l}-0.023^{* * *} \\
(0.004)\end{array}$ & $\begin{array}{l}-0.056 * \star \star \\
(0.008)\end{array}$ \\
\hline Western countries & $\begin{array}{c}-0.020^{\star \star \star} \\
(0.004)\end{array}$ & $\begin{array}{l}- \\
-\end{array}$ & $\begin{array}{c}-0.021^{* * *} \\
(0.005)\end{array}$ & $\begin{array}{l}-0.050 * * * \\
(0.008)\end{array}$ \\
\hline Eastern Europe & $\begin{array}{c}-0.044^{\star \star \star} \\
(0.008)\end{array}$ & $\begin{array}{l}-0.008^{*} \\
(0.004)\end{array}$ & $\begin{array}{l}- \\
-\end{array}$ & $\begin{array}{l}-0.039 * * * \\
(0.010)\end{array}$ \\
\hline Non-W., Non-Europe & $\begin{array}{c}-0.068^{\star \star *} \\
(0.009)\end{array}$ & $\begin{array}{l}-0.008 \\
(0.003)\end{array}$ & $\begin{array}{l}-0.016 * * \\
(0.006)\end{array}$ & $\begin{array}{l}- \\
-\end{array}$ \\
\hline Firm size dummies & Yes & Yes & Yes & Yes \\
\hline Mun-Ind-Year dummies & Yes & Yes & Yes & Yes \\
\hline Observations & 766,983 & 766,983 & 766,983 & 766,983 \\
\hline $\mathrm{R}^{2}$ & 0.195 & 0.157 & 0.158 & 0.171 \\
\hline \multicolumn{5}{|c|}{$\begin{array}{l}\text { Notes: Each column represents a separate regression. }{ }^{*},{ }^{* *} \text { and }{ }^{* * *} \text { denote statistical significance at } 10 / 5 / 1 \text { percent level } \\
\text { respectively. Standard errors robust for serial correlation at the establishment level are shown in parentheses. The } \\
\text { estimated model is a linear probability model where the dependent variable indicates whether the new hire belongs to } \\
\text { each of the groups in column (1)-(4). Industry codes are at the } 5 \text {-digit establishment level. The sample consists of } \\
\text { establishments with less than } 50 \text { employees and all regressions include controls for establishment size of ten employee } \\
\text { intervals. Each regression also controls for the share of immigrants that origin from the group corresponding to the } \\
\text { dependent variable. }\end{array}$} \\
\hline
\end{tabular}


Table B3 Starting wage effects of origin similarity between hire and manager's ethnicity

\begin{tabular}{|c|c|c|c|c|}
\hline & \multicolumn{4}{|c|}{ Dependent variable: Log monthly wage } \\
\hline & $(1)$ & $(3)$ & $(4)$ & $(5)$ \\
\hline Both immigrant & $\begin{array}{c}0.013 \\
(0.013)\end{array}$ & $\begin{array}{c}0.009 \\
(0.011)\end{array}$ & $\begin{array}{c}0.012 \\
(0.011)\end{array}$ & $\begin{array}{c}0.017 \\
(0.019)\end{array}$ \\
\hline Both same immigrant country & $\begin{array}{l}- \\
-\end{array}$ & - & $\begin{array}{l}-0.017 \\
(0.025)\end{array}$ & $\begin{array}{l}-0.023 \\
(0.051)\end{array}$ \\
\hline Immigrant manager & $\begin{array}{c}0.012 \\
(0.009)\end{array}$ & $\begin{array}{c}0.008 \\
(0.008)\end{array}$ & $\begin{array}{c}0.008 \\
(0.008)\end{array}$ & $\begin{array}{c}0.011 \\
(0.010)\end{array}$ \\
\hline Immigrant hire & $\begin{array}{c}-0.060^{\star \star \star *} \\
(0.002)\end{array}$ & $\begin{array}{c}-0.048^{\star \star \star \star} \\
(0.002)\end{array}$ & $\begin{array}{c}-0.048^{\star \star \star} \\
(0.002)\end{array}$ & $\begin{array}{c}-0.022^{\star \star \star} \\
(0.003)\end{array}$ \\
\hline Individual characteristics & & & & \\
\hline Age & $\begin{array}{c}0.019 \star \star \star \\
(0.000)\end{array}$ & $\begin{array}{c}0.016 * \star \star \\
(0.000)\end{array}$ & $\begin{array}{c}0.016 * \star \star \\
(0.000)\end{array}$ & $\begin{array}{c}0.009 \star \star \star \\
(0.000)\end{array}$ \\
\hline $\mathrm{Age}^{2}$ & $\begin{array}{c}-0.000^{* * *} \\
(0.000)\end{array}$ & $\begin{array}{c}-0.000^{\star * *} \\
(0.000)\end{array}$ & $\begin{array}{c}-0.000^{\star \star \star} \\
(0.000)\end{array}$ & $\begin{array}{c}-0.000^{\star * \star} \\
(0.000)\end{array}$ \\
\hline Female & $\begin{array}{c}-0.045^{\star \star *} \\
(0.001)\end{array}$ & $\begin{array}{c}-0.029^{\star \star *} \\
(0.001)\end{array}$ & $\begin{array}{c}-0.030 \star \star \star \\
(0.001)\end{array}$ & $\begin{array}{c}-0.013^{\star * *} \\
(0.002)\end{array}$ \\
\hline Educational level & & & & \\
\hline Compulsory long & $\begin{array}{c}0.053^{\star * *} \\
(0.003)\end{array}$ & $\begin{array}{c}0.037^{\star \star * *} \\
(0.002)\end{array}$ & $\begin{array}{c}0.037^{\star \star \star *} \\
(0.002)\end{array}$ & $\begin{array}{c}0.004 \\
(0.004)\end{array}$ \\
\hline Secondary short & $\begin{array}{c}0.063^{\star \star *} \\
(0.002)\end{array}$ & $\begin{array}{l}0.048^{\star \star \star} \\
(0.002)\end{array}$ & $\begin{array}{c}0.048^{\star \star \star} \\
(0.002)\end{array}$ & $\begin{array}{c}0.013^{\star * *} \\
(0.003)\end{array}$ \\
\hline Secondary long & $\begin{array}{c}0.092^{\star \star \star} \\
(0.003)\end{array}$ & $\begin{array}{c}0.062^{\star \star \star} \\
(0.002)\end{array}$ & $\begin{array}{c}0.062^{\star \star \star} \\
(0.002)\end{array}$ & $\begin{array}{c}0.023^{\star \star \star} \\
(0.003)\end{array}$ \\
\hline University short & $\begin{array}{c}0.154^{\star * *} \\
(0.002)\end{array}$ & $\begin{array}{c}0.088^{\star \star *} \\
(0.002)\end{array}$ & $\begin{array}{c}0.088^{\star * *} \\
(0.002)\end{array}$ & $\begin{array}{c}0.042^{\star * *} \\
(0.004)\end{array}$ \\
\hline University long & $\begin{array}{c}0.238^{\star * *} \\
(0.003)\end{array}$ & $\begin{array}{c}0.128^{\star * *} \\
(0.003)\end{array}$ & $\begin{array}{c}0.128^{\star * *} \\
(0.003)\end{array}$ & $\begin{array}{c}0.058^{\star * *} \\
(0.004)\end{array}$ \\
\hline $\mathrm{PhD}$ & $\begin{array}{c}0.392^{\star * *} \\
(0.013)\end{array}$ & $\begin{array}{c}0.257 * * * \\
(0.013)\end{array}$ & $\begin{array}{c}0.257^{\star \star \star *} \\
(0.013)\end{array}$ & $\begin{array}{c}0.106^{\star * *} \\
(0.018)\end{array}$ \\
\hline Establishment size & & & & \\
\hline 10-19 employees & $\begin{array}{c}0.020 \star \star \star \\
(0.003)\end{array}$ & $\begin{array}{c}0.020^{\star \star \star} \\
(0.003)\end{array}$ & $\begin{array}{c}0.020^{\star \star \star} \\
(0.003)\end{array}$ & $\begin{array}{c}0.006 \\
(0.005)\end{array}$ \\
\hline 20-29 employees & $\begin{array}{c}0.037^{\star \star *} \\
(0.004)\end{array}$ & $\begin{array}{l}0.038^{\star * *} \\
(0.003)\end{array}$ & $\begin{array}{c}0.038^{\star \star \star *} \\
(0.003)\end{array}$ & $\begin{array}{l}0.013^{\star \star \star} \\
(0.006)\end{array}$ \\
\hline 30-39 employees & $\begin{array}{c}0.056^{\star \star *} \\
(0.004)\end{array}$ & $\begin{array}{c}0.056^{\star \star *} \\
(0.004)\end{array}$ & $\begin{array}{c}0.056^{\star \star \star} \\
(0.004)\end{array}$ & $\begin{array}{c}0.017^{\star * *} \\
(0.006)\end{array}$ \\
\hline 40-49 employees & $\begin{array}{c}0.074^{\star * *} \\
(0.005)\end{array}$ & $\begin{array}{c}0.075^{\star \star *} \\
(0.004)\end{array}$ & $\begin{array}{c}0.075^{\star \star \star} \\
(0.004)\end{array}$ & $\begin{array}{c}0.023^{\star * *} \\
(0.007)\end{array}$ \\
\hline Establishment dummies & Yes & Yes & Yes & Yes \\
\hline Occupational dummies (2-digit) & - & Yes & Yes & Yes \\
\hline Wage in prev. job & - & - & - & Yes \\
\hline Observations & 205,811 & 205,811 & 205,811 & 71,311 \\
\hline $\mathrm{R}^{2}$ & 0.661 & 0.723 & 0.723 & 0.892 \\
\hline
\end{tabular}

